\title{
Analysis of Performance Improvement on PT. Distribusi Air Santri (PT. DAS) Using Business Model Canvas
}

\author{
Zeniar Adzmizah $^{1}$ and Moses Laksono Singgih ${ }^{2}$ \\ ${ }^{1}$ Department of Management Technology, Institut Teknologi Sepuluh Nopember, Surabaya \\ ${ }^{2}$ Department of Industrial and System Engineering, Institut Teknologi Sepuluh Nopember, Surabaya \\ e-mail: moseslsinggih@ie.its.ac.id
}

\begin{abstract}
Since 1975, the drinking habits of the Indonesian people began to change from being merely boiling water from tap to bottled water (AMDK), thus encourage drinking water producers to continue branch out in market share. In 2013, the market share of AMDK industry was Rp 22.51T and there were around 500 competing AMDK companies. PT. Distribusi Air Santri (PT. DAS) is a company engaged in the distribution of "Air Mineral Santri" brand which located in Surabaya. This company aims to increase the market in Surabaya by $10 \%$ or sell 142,000 items / month. So to achive company goals, company need to develop business models and plan business strategies using Business Model Canvas (BMC). In the BMC analysis, an analysis of environmental conditions was carried out using the 7sMcKinsey method, External Scanning and porter strength analysis. And validation is needed so that BMCs are made accurately and precisely with the help of a SWOT analysis.
\end{abstract}

Keywords—Business Model Canvas, SWOT Analysis.

\section{INTRODUCTION}

$\mathrm{T}$ HE Bottled Drinking Industry in Indonesia (AMDK) began to develop since 1973, the Indonesian people began to change the habit of consuming water from boiled water to bottled drinking water (AMDK), which encouraged the producers of bottled drinking water to develop. According to the Indonesian Bottled Drinking Water Association (ASPADIN), in 2013, AMDK's market value was IDR 22.51 trillion and this industry will continue to grow $11.1 \%$ every year. This provides an opportunity for drinking water producers to compete in the bottled water market (AMDK).

Table 1 explains the assumptions of the needs and potential market of the AMDK in Surabaya. According to DISPENDUKCAPIL, in January 2019 the population of the city of Surabaya reached 3 million people. Meanwhile according to ASPADIN, $60 \%$ of Indonesian people consume bottled drinking water. If it is assumed that the price of 1 liter of water is IDR 1,000 , the potential market of AMDK in Surabaya is IDR $27,000,000,000 /$ month. If the price per item is IDR 20,000. So the need for bottled water in Surabaya is 1,350,000 items / month. That is can be seen at Table 2 .

PT. Distribusi Air Mineral (PT.DAS) is the main distributor of AMDK Air Mineral Santri in Surabaya. AMDK Air Mineral Santri is mineral water that uses natural raw materials taken from Umbulan's water springs, producing a large enough water discharge so that it's guaranteed quality, clarity, freshness and stability of mineral content. Raw
Table 1

AMDK's Needs in Surabaya

\begin{tabular}{ccc}
\multicolumn{3}{c}{ AMDK's Needs in Surabaya } \\
\hline \hline \multicolumn{3}{c}{ AMDK's Needs in Surabaya } \\
\hline Surabaya's population & 3.000 .000 people \\
AMDK's consumption & $60 \%$ people & 1.800 .000 people \\
Assumption of AMDK's & $500 \mathrm{ml} /$ day & $900.000 .000 \mathrm{ml} /$ day \\
needs/day & & \\
Assumption of AMDK's needs & $27.000 .000 \mathrm{~L} / \mathrm{month}$ \\
/month & \\
\hline \hline
\end{tabular}

Table 2.

Potential market of AMDK in Surabaya

Potential market of AMDK in Surabaya
Assumption of AMDK's needs /month price of 1 liter of water potential market of AMDK in Surabaya

Assumption price per item

AMDK's Sales in Surabaya/Month
27.000.000
L/month

$\operatorname{Rp} 1.000$, $\mathrm{Rp}$ 27.000.000.000, /month $\mathrm{Rp}$
20.000 /item

1.350 .000 item/Bulan materials are processed with Carbon Filter, Sand Filter, then sterilized using Technology Water Treatment (TWT) which is adjusted to the Indonesian National Standard (SNI) with ultraviolet light and ozone (O3).

Sales of AMDK Air Mineral Santri in 2019 are 60,000 items/month, or about $4.5 \%$ Air Santri controls the AMDK market in Surabaya. This company plan to increase sales in 2020 by controlling AMDK's market in Surabaya by $10 \%$ or selling 142,000 items/month.

The company needs to plan business strategies to achieve company goals, one of the solution is plan a business model that consists of various elements that can describe the strategy, goals, structure, technology, processes, value for customers so that companies can compete well in the business market. The business model helps to describe all sources of competitive advantage possessed by an organization that distinguishes it from company positioning of products in the same industry. In addition, the business model is also a value chain structure, creating value by defining a series of activities ranging from raw materials to raw materials to the final customer, where the specified value is added to the overall activity. Figure 1 describe the sales of of AMDK Air Mineral Santri by PT. DAS per year.

In this study, the research conducted to analyze the business model using Business Model Canvas (BMC) 
The $6^{\text {th }}$ International Seminar on Science and Technology (ISST) 2020

July $25^{\text {th }}$, 2020, Institut Teknologi Sepuluh Nopember, Surabaya, Indonesia

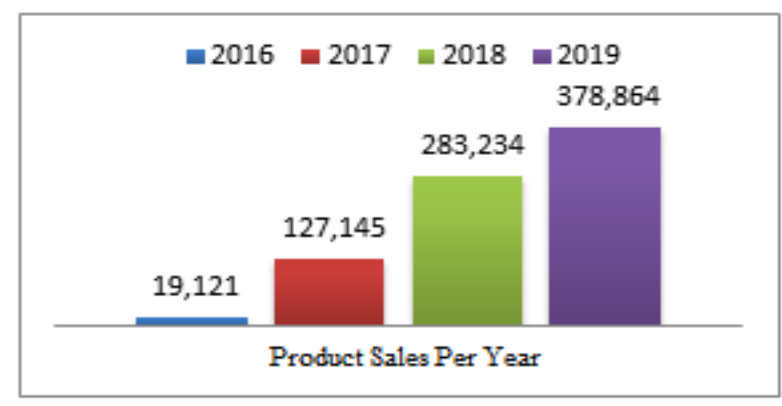

(a)

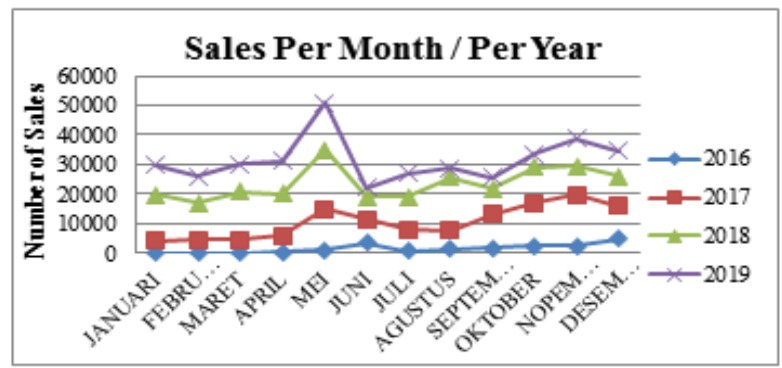

(b)

Figure 1. (a) Sales chart of AMDK Air Santri by PT. DAS per year; (b) Sales chart of AMDK Air Santri by PT. DAS per month / per year.

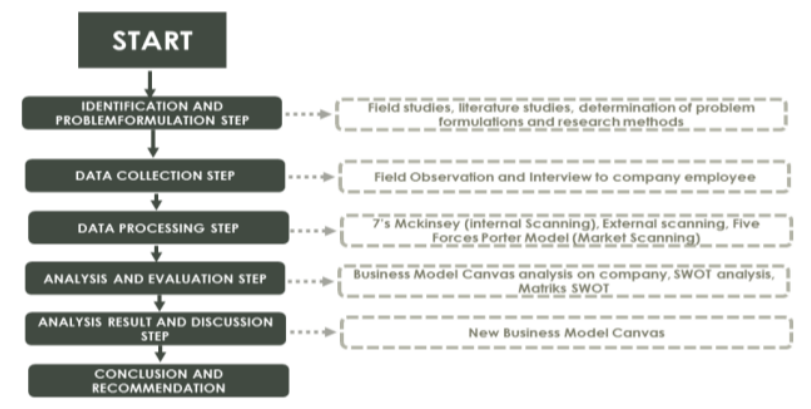

Figure 2. Method.

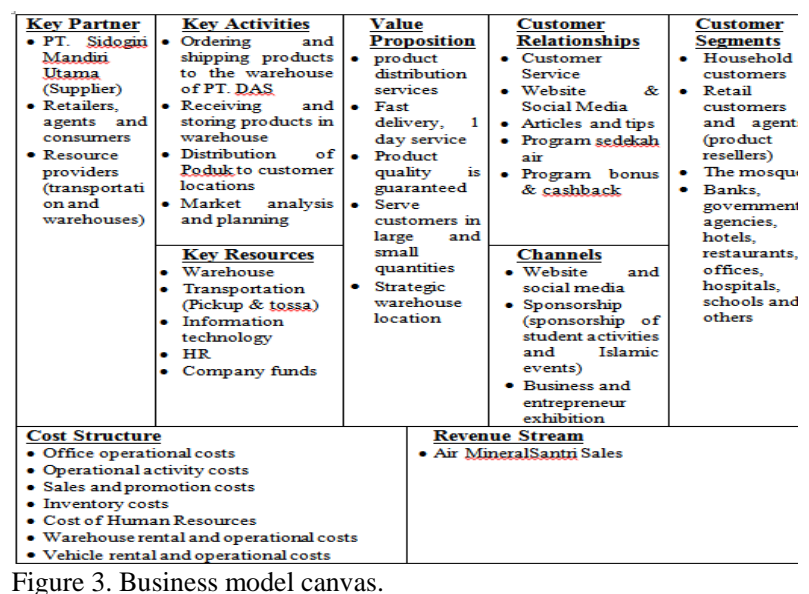

alongside with SWOT Analysis. The Business Model Canvas is a business model that develops a business unit and has 9 components, each component can be the first step to determine where the company develops its business model business. An effective way to evaluate company business models is to combine the classic SWOT analysis with the business model canvas. The objectives of the research to develop business models using the Business Model Canvas approach with the help of a SWOT analysis.
Table 3.

Analysis of 7's mckinsey

\begin{tabular}{|c|c|c|}
\hline Attribute & Definition & Analysis Results \\
\hline Strategy & $\begin{array}{l}\text { Organizational } \\
\text { strategies used to } \\
\text { achieve } \\
\text { company goals } \\
\text { (internal } \\
\text { company) }\end{array}$ & 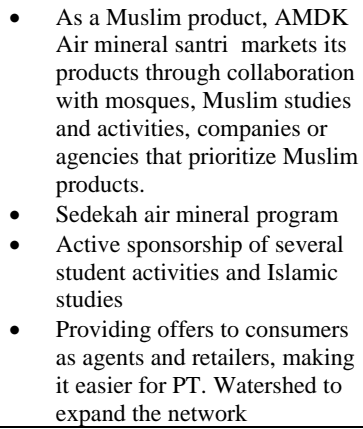 \\
\hline Structure & $\begin{array}{l}\text { The structural } \\
\text { concept of the } \\
\text { company, the } \\
\text { responsibilities } \\
\text { of each job }\end{array}$ & $\begin{array}{l}\text { the organizational structure is } \\
\text { divided 3. Man. Operations } \\
\text { related to products and } \\
\text { customers. Man Development } \\
\text { for administration, finance and } \\
\text { HR. Meanwhile, Man. } \\
\text { Marketing for business strategy } \\
\text { and company marketing }\end{array}$ \\
\hline System & $\begin{array}{l}\text { The method used } \\
\text { to ensure the } \\
\text { work is done } \\
\text { well and the } \\
\text { strategy to the } \\
\text { evaluation }\end{array}$ & $\begin{array}{l}\text { The company already has an } \\
\text { SOP containing a job } \\
\text { description for each employee } \\
\text { from what needs to be done to } \\
\text { the work process for each job } \\
\text { One-way work systems, } \\
\text { managers assign tasks to staff, } \\
\text { then staff complete tasks, there } \\
\text { is no gap for staff to make } \\
\text { improvements to work }\end{array}$ \\
\hline Shared Value & $\begin{array}{l}\text { The values that } \\
\text { are instilled by } \\
\text { the company }\end{array}$ & $\begin{array}{l}\text { Religious values, kinship and } \\
\text { good cooperation. } \\
\text { Understand the conditions of } \\
\text { each employee and help one } \\
\text { another } \\
\text { - Providing facilities and } \\
\text { facilities for employees to work } \\
\text { productively }\end{array}$ \\
\hline Style & $\begin{array}{ll}\text { Leadership } & \\
\text { systems } & \text { that } \\
\text { affect } & \text { the } \\
\text { company } & \end{array}$ & $\begin{array}{l}\text { Instructive leadership style is a } \\
\text { style that directly gives } \\
\text { direction (instruction) work } \\
\text { specifically to subordinates. } \\
\text { Managers tend to have a } \\
\text { strategy that provides direct } \\
\text { instruction }\end{array}$ \\
\hline Staff & $\begin{array}{l}\text { Company human } \\
\text { resources, } \\
\text { employee } \\
\text { recruitment } \\
\text { systems, } \\
\text { performance } \\
\text { appraisals, } \\
\text { rewards }\end{array}$ & 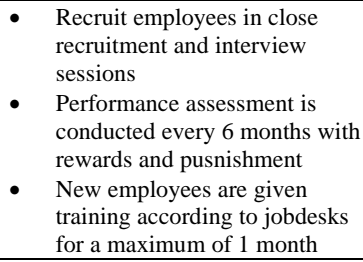 \\
\hline Skills & $\begin{array}{l}\text { Development of } \\
\text { ammlarras stills }\end{array}$ & - Only provide training to \\
\hline
\end{tabular}

\section{METHOD}

Data collection and processing in this chapter is obtained from the results of field observations and interviews with managers and employees. The results of the company's condition analysis are managed in the form of 7's Mckinsey analysis, external scanning and five forces porter model.

7's Mckinsey is a framework for analyzing how effective an organization is to achieve organizational goals which described through 7 elements namely strategy, structure, system, shared values, skills, style and staff. In the analysis of 7's Mckinsey in this research, the most emphasized thing by the company is to increase product sales and disseminate the brand "AMDK Air Mineral Santri" so that it is better known to the public. 
Table 4.

Analysis of external scanning

\begin{tabular}{lll}
\hline \hline \multicolumn{1}{c}{ Attribute } & \multicolumn{1}{c}{ Definition } & \multicolumn{1}{c}{ Result Analysis } \\
\hline $\begin{array}{l}\text { Natural } \\
\text { Environment }\end{array}$ & $\begin{array}{l}\text { environmental, natural and } \\
\text { geographical }\end{array}$ & $\begin{array}{l}\text { Warehouse location of PT. Santri Water Distribution is not known by the wider community so } \\
\text { it is safer from competitors' disturbances } \\
\text { Surabaya's dry weather makes it easy to deliver products using pickups } \\
\text { The location of the warehouse is quite strategic for shipping the Surabaya area (There are 3 } \\
\text { warehouses) }\end{array}$ \\
\hline Technology & $\begin{array}{l}\text { facility, an invention, information } \\
\text { and communication technology }\end{array}$ & $\begin{array}{l}\text { Ordering products can be done online } \\
\text { Marketing management is mostly done through information technology }\end{array}$ \\
\hline $\begin{array}{l}\text { External } \\
\text { Stakeholder }\end{array}$ & $\begin{array}{l}\text { sponsors, vendors, suppliers or } \\
\text { outside organizations that help } \\
\text { achieve the company's goals }\end{array}$ & $\begin{array}{l}\text { Supplier of Air Mineral Santri only PT. Sidogiri Mandiri Utama } \\
\text { Warehouses and transportation equipment used by PT. DAS is the result of collaboration with } \\
\text { other parties }\end{array}$ \\
\hline Socioculture & $\begin{array}{l}\text { values, customs, character, culture } \\
\text { and habits of the people. }\end{array}$ & $\begin{array}{l}\text { The habit of drinking bottled mineral water, is more practical and guaranteed quality } \\
\text { People tend to use foreign products or products that are famous for expensive prices }\end{array}$ \\
\hline \hline
\end{tabular}

Table 5.

Analysis of external scanning

\begin{tabular}{|c|c|c|}
\hline Attribute & Definition & Result Analysis \\
\hline Threat of New Entrants & $\begin{array}{l}\text { The threat of corporate competitors from new } \\
\text { competitors. This causes companies have to share } \\
\text { profits and market attractiveness with other } \\
\text { companies. }\end{array}$ & $\begin{array}{l}\text { The threat of corporate competitors from new competitors. This } \\
\text { causes companies to share profits and market attractiveness with } \\
\text { other companies. }\end{array}$ \\
\hline $\begin{array}{l}\text { Bargaining Power of } \\
\text { Suppliers }\end{array}$ & $\begin{array}{l}\text { Suppliers have the power to increase and decrease } \\
\text { product prices and quality }\end{array}$ & $\begin{array}{l}\text { PT. Sidogiri Mandiri Utama is a product supplier. } \\
\text { In maintaining good relations, PT. DAS helps suppliers in the field } \\
\text { of marketing and product branding, as well as helping cooperation } \\
\text { with consumers in the Surabaya area. }\end{array}$ \\
\hline $\begin{array}{l}\text { Bargaining Power of } \\
\text { Consumer }\end{array}$ & $\begin{array}{l}\text { Customers want to get quality products at } \\
\text { affordable prices. }\end{array}$ & $\begin{array}{l}\text { Customers can get lower prices by collaborating with PT. DAS, a } \\
\text { minimum order of product } 50 \text { items / shipping, customers will get } \\
\text { a bonus } \\
\text { Or enter into an MoU agreement with conditions agreed by two } \\
\text { parties }\end{array}$ \\
\hline Threat of Subtitute Products & $\begin{array}{l}\text { Threats from products that have the same function } \\
\text { and / or have better quality and more affordable } \\
\text { prices. }\end{array}$ & $\begin{array}{l}\text { Produk lain yang memiliki fungsi yang sama dengan air mineral } \\
\text { adalah air kelapa, teh herbal, air lemon atau infused water. } \\
\text { Saat ini ada beberapa merk yang memproduksi dan memasarkan } \\
\text { produk dengan bahan tersebut, karena lebih memiliki rasa. } \\
\text { Namun kebutuhan akan air mineral tidak mudah tergantikan } \\
\text { seutuhnya dengan produk lain sehingga penjualan air minum masih } \\
\text { lebih unggul daripada produk minuman lain }\end{array}$ \\
\hline $\begin{array}{l}\text { Competitive Rivalry within } \\
\text { the Industry }\end{array}$ & $\begin{array}{l}\text { Competition that occurs between one company } \\
\text { and another to become a company that controls the } \\
\text { market. }\end{array}$ & $\begin{array}{l}\text { According to ASPADIN (there are already } 700 \text { registered } \\
\text { companies of Bottled Drinking Water in Indonesia }\end{array}$ \\
\hline
\end{tabular}

In the external analysis for environmental scanning there are several components contained that function to analyze the condition of the company with external parties, namely natural environment, technology, external stakeholders, socio culture. In addition for external analysis, porter's five force model method is used to analyze companies on developing business strategies in the market. According to Porter, there are 5 things that determine the level of competition and product attractiveness in the Market, namely Threat of New Entrants, Bargaining Power of Suppliers, Bargaining Power of Consumer, Threat of Substitute Products and Rivalry within the Industry.

In the Business Model Canvas analysis at PT. DAS is carried out discussions and interviews with managers and employees from various divisions who act as respondents to define the business model canvas that is currently used by companies. The Business Model Canvas consists of 9 components, there is key partners, key activities, key resources, value proposition, customer relationships, channels, customer segments, cost structure, revenue stream.

SWOT analysis is shown by mapping the components of strengths, opportunities, weaknesses and threats of a company. In making a good SWOT analysis, the company must be as objective as possible to assess the company but also through consumer testimonials. SWOT analysis is performed on every element in the Business Model Canvas analysis which aims to perfect the business model owned by the company. For detail can see Figure 2 about method.

\section{RESULT}

\section{A. Analysis of 7's Mckinsey}

Analysis of 7's Mckinsey can be seen at Table 3, where explain about definition of a attribute and analysis result about the attribute.

\section{B. Analysis of external scanning}

Analysis of external scanning can be seen at Table 4, where explain about definition of a attribute and analysis result about the attribute.

\section{Analysis of Porter's five forces model}

Analysis of Porter's five forces model can be seen at Table 5 , where explain about definition of a attribute and analysis result about the attribute.

\section{1) Analysis of Business Model Canvas}

Bussiness Model Canvas can be seen in Figure 3. For explain about it can be read in below. 
The $6^{\text {th }}$ International Seminar on Science and Technology (ISST) 2020

July $25^{\text {th }}$, 2020, Institut Teknologi Sepuluh Nopember, Surabaya, Indonesia

Table 6.

Analysis SWOT

\begin{tabular}{|c|c|c|c|c|}
\hline $\begin{array}{l}\text { Attribute } \\
\text { BMC }\end{array}$ & Strength $(\mathrm{S})$ & Weakness (W) & Opportunity (O) & Threat $(\mathrm{T})$ \\
\hline Key Partners & $\begin{array}{l}\text { Have and establish good } \\
\text { relationships with company } \\
\text { partners }\end{array}$ & $\begin{array}{l}\text { consumers, retailers and agents, } \\
\text { tend to want lower product } \\
\text { prices with maximum service }\end{array}$ & $\begin{array}{l}\text { Current partners can help } \\
\text { expand the network } \\
\text { Opportunities to expand } \\
\text { cooperation with potential } \\
\text { companies }\end{array}$ & $\begin{array}{l}\text { Partners who are not } \\
\text { satisfied with PT. DAS can } \\
\text { end collaboration }\end{array}$ \\
\hline $\begin{array}{l}\text { Key } \\
\text { Activities }\end{array}$ & $\begin{array}{l}\text { The factory works very } \\
\text { professionally, the number of } \\
\text { products and the time is } \\
\text { always right } \\
\text { Managers always monitor } \\
\text { employee performance } \\
\text { Operational activities are } \\
\text { always carried out according } \\
\text { to plan }\end{array}$ & $\begin{array}{l}\text { The product is damaged due to } \\
\text { the shipping or storage process } \\
\text { HR does not comply with the } \\
\text { SOP given by the manager } \\
\text { Miscommunication with } \\
\text { customers often occurs } \\
\text { Too focused on online marketing }\end{array}$ & $\begin{array}{l}\text { The existence of technology } \\
\text { and information media make } \\
\text { it easy in business matters }\end{array}$ & $\begin{array}{l}\text { Marketing teams tend to wait } \\
\text { for the ball rather than } \\
\text { picking up the ball about } \\
\text { prospective agents, retailers, } \\
\text { or new partners }\end{array}$ \\
\hline $\begin{array}{l}\text { Key } \\
\text { Resources }\end{array}$ & $\begin{array}{l}\text { The number of human } \\
\text { resources owned by the } \\
\text { company is sufficient for } \\
\text { operational activities } \\
\text { Strategic warehouse location }\end{array}$ & $\begin{array}{l}\text { Lack of HR depletes operational } \\
\text { work (1 warehouse only has } 1 \\
\text { admin) } \\
\text { Only } 1 \text { warehouse has vehicles } \\
\text { according to shipping } \\
\text { requirements }\end{array}$ & $\begin{array}{l}\text { The company has the } \\
\text { opportunity to add resources } \\
\text { in the form of HR and } \\
\text { vehicles because adding } \\
\text { resources provides } \\
\text { convenience and fluency in } \\
\text { work }\end{array}$ & $\begin{array}{l}\text { The marketing team makes } \\
\text { more use of online } \\
\text { marketing, can be a threat } \\
\text { the company cannot develop } \\
\text { optimally in the market }\end{array}$ \\
\hline $\begin{array}{l}\text { Value } \\
\text { Proposition }\end{array}$ & $\begin{array}{l}\text { Distributing professionally } \\
\text { Fast delivery } \\
\text { Product quality is guaranteed } \\
\text { Satisfy customers as needed }\end{array}$ & $\begin{array}{l}\text { The product is still new so the } \\
\text { proportion of values is not } \\
\text { widely known }\end{array}$ & $\begin{array}{l}\text { Products have a chance to sell } \\
\text { in the market because of } \\
\text { guaranteed product quality } \\
\text { and good service }\end{array}$ & $\begin{array}{l}\text { Substitution products and } \\
\text { products from competing } \\
\text { brands }\end{array}$ \\
\hline $\begin{array}{l}\text { Customer } \\
\text { Relationships }\end{array}$ & $\begin{array}{l}\text { Has many programs that can } \\
\text { establish good relationships } \\
\text { with old customers and add } \\
\text { new customers }\end{array}$ & - & $\begin{array}{l}\text { Opportunities to work with } \\
\text { customers create an event that } \\
\text { enhances the relationship } \\
\text { between the company and } \\
\text { regular customers }\end{array}$ & $\begin{array}{l}\text { If the company's products or } \\
\text { services are not satisfactory, } \\
\text { customers can switch to } \\
\text { other brands }\end{array}$ \\
\hline Channels & $\begin{array}{l}\text { There is a media to increase } \\
\text { relationships with customer }\end{array}$ & $\begin{array}{l}\text { Owned channels have not been } \\
\text { able to reach new customers }\end{array}$ & $\begin{array}{l}\text { The development of } \\
\text { information technology and } \\
\text { media facilitates the } \\
\text { dissemination of information }\end{array}$ & $\begin{array}{l}\text { Competitors may take the } \\
\text { similar steps }\end{array}$ \\
\hline $\begin{array}{l}\text { Customer } \\
\text { Segments }\end{array}$ & $\begin{array}{l}\text { Products can be offered to } \\
\text { various types of customers } \\
\text { because of universal products } \\
\text { and guaranteed quality }\end{array}$ & $\begin{array}{l}\text { Some customers who are used to } \\
\text { using other brands, do not want } \\
\text { to use other brands }\end{array}$ & $\begin{array}{l}\text { Opportunities to expand the } \\
\text { network by maximizing the } \\
\text { marketing team }\end{array}$ & $\begin{array}{l}\text { Customer segment can be } \\
\text { reduced if the competitor } \\
\text { company maximizes the } \\
\text { value proposition, channels } \\
\text { and key resources }\end{array}$ \\
\hline $\begin{array}{l}\text { Cost } \\
\text { Structure } \\
\end{array}$ & $\begin{array}{l}\text { Efficient and good financial } \\
\text { management }\end{array}$ & Changes in operational costs & - & Unforeseen costs \\
\hline $\begin{array}{l}\text { Revenue } \\
\text { Stream }\end{array}$ & $\begin{array}{l}\text { Have a sustainable source of } \\
\text { income from your } \\
\text { collaboration with customers }\end{array}$ & $\begin{array}{l}\text { Only has one source of income } \\
\text { (Santri's AMDK sales) } \\
\text { Includes new products that do } \\
\text { not have affordable prices }\end{array}$ & $\begin{array}{l}\text { Opportunity to sell other } \\
\text { types of products, such as the } \\
\text { Santri AMDK merchandise } \\
\text { Opportunities to expand } \\
\text { cooperation with more other } \\
\text { large companies }\end{array}$ & $\begin{array}{l}\text { Competition with other } \\
\text { bottled water products }\end{array}$ \\
\hline
\end{tabular}

1. Key Partners : Other parties who work with companies to achieve company goals

2. Key Activities: The main activities undertaken by the company are key to the success of the company

3. Key Resources : Resources owned by the company or elements in the company that play a role in achieving company goals.

4. Value Proposition The proportion of the value of a product that is the reason consumers use the product (quality, price, brand, design, service, guarantee, ease of access, etc.).

5. Customer Relationships : Steps or programs owned by the company to establish good relationships with customers to retain old customers and get new customers.

6. Channels : The media used to communicate, convey values and establish relationships with customers.
7. Customer Segments : Mapping customer segments or grouping customers according to the value offered by the company.

8. Cost Structure : Details of all costs used by the company for company activities. All costs to be incurred by the company have been calculated beforehand.

9. Revenue Stream : Revenues earned by the company from the company's key activities.

\section{2) Analysis $S W O T$}

For the analysis of SWOT, each variable of business model canvas is being analyze with SWOT criteria that is strength, weakness, opportunity and threat. Analysis SWOT can see in Table 6. 
The $6^{\text {th }}$ International Seminar on Science and Technology (ISST) 2020

July $25^{\text {th }}, 2020$, Institut Teknologi Sepuluh Nopember, Surabaya, Indonesia

\section{3) SWOT Matrix Analysis}

Table 7.

Internal SWOT Matrix Analysis

\begin{tabular}{|c|c|c|c|}
\hline & 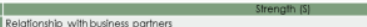 & Bobot & Raling inscore \\
\hline & 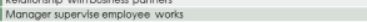 & 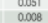 & \\
\hline & Operofilond octivines are caried out oce & & 0.009 \\
\hline & lokess avdare strateols & & \\
\hline & 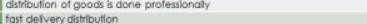 & 0.045 & a18 0 \\
\hline & Product audity quaranteod & 0.124 & 象 \\
\hline & follatir castomers as needded & & \\
\hline 0 & 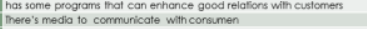 & $\begin{array}{l}0.0007 \\
0.006 \\
0\end{array}$ & 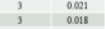 \\
\hline II: & 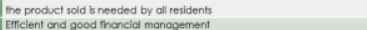 & 0.076 & 0.304 \\
\hline & 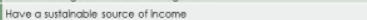 & & \\
\hline & (1) & Bobot & 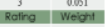 \\
\hline is & 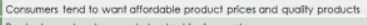 & 0.021 & 0.021 \\
\hline & 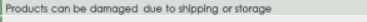 & 0.087 & 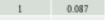 \\
\hline 16 & sDM does not comply with the SOP given by the manoger & 0.039 & 0099 \\
\hline 18 & 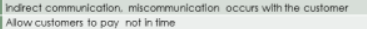 & $\begin{array}{l}0.07 \\
0.013\end{array}$ & .0.13 \\
\hline 10 & need to odd emploveroes to speod up wark & $0.003+$ & \\
\hline & lack of marketing emplayees & 0.014 & 0.014 \\
\hline$\frac{12}{22}$ & 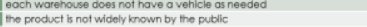 & 0.058 & 些8 \\
\hline 23 & 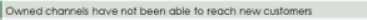 & 0.028 & \\
\hline 25 & 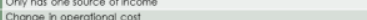 & & 0033 \\
\hline & & & 1.63 \\
\hline
\end{tabular}

Table 8.

External SWOT Matrix Analysis

\begin{tabular}{|c|c|c|c|c|}
\hline & \multirow{2}{*}{ Atribut Peluang (0) } & \multicolumn{3}{|c|}{ Bobot Rating Weig } \\
\hline & & 0.026 & 3 & 0.077 \\
\hline 2 & easet to expand cooperation with other companies & 0.018 & 4 & 0.07 \\
\hline 3 & the evistence of technology and information media makesit easyt treach customers & 0.115 & 4 & 0.46 .53 \\
\hline 4 & opportunity to add resources (employee, Warehouse and vehicles) & 0.018 & 3 & \\
\hline & the product will sell well on the market because of guaranteed quality and professional service & 0.066 & 3 & 0.19 \\
\hline 6 & custom channels by creating events with regular customers to improve relationships & & & \\
\hline 7 & maximize offline marketing w $\mathrm{w}$ & 0.085 & 3 & \\
\hline 8 & selling products other than AMDK Santri (such as merchandise,etc.) & 0.04 & 3 & 0.12 \\
\hline & Atribut Ancaman (n) & & Uating & \\
\hline & Partners who are not satisfied with PT. DAS can stop cooperation & 0.189 & 2 & 0.37 \\
\hline 10 & and not maximally attracts news & 0.074 & 1 & 0.07. \\
\hline u & offline marketi & 0.052 & $i$ & 0.05 \\
\hline 12 & many substitute products & 0.015 & 1 & \\
\hline 13 & custome & 0.025 & 1 & $0.02:>2>3$ \\
\hline 14 & If the company's products or services are not satisfac & 0.145 & 1 & 0.14 \\
\hline 15 & competing companies take similar steps & 0.011 & 2 & \\
\hline
\end{tabular}

In this step, analyze the power between internal and external component of company, strength and weakness variable for internal, while opportunity and threat variable for external. As describe at Table 7 and Table 8.

\section{4) New Business Model Canvas}

New Bussiness Model Canvas can be seen in Table 9. This section explain about new business model canvas at this case.

\section{CONCLUSION}

Utilizing partners to expand the network to various new partners and collaborate with other companies. Adding other sources of income aside from selling Air Mineral Santri. Routinely provide punishment and reward to employees to increase employee motivation. The company should focus on attracting and selling products to agents and retailers. Distribute small consumer purchases to agents and retailers.

\section{REFERENCES}

[1] Aguilar, F. J. (1967). Scanning the Business Environment. New York: Macmillan Co.

[2] Chesbrough, H. (2010). Business model innovation: Opportunities and barriers. Long Range Planning.
[3] Hunger, \& Wheelen. (2000). Manajemen Strategi. Yogyakarta: Andi.

Table 9.

New business model canvas

\begin{tabular}{|c|c|c|c|c|}
\hline \multirow[t]{2}{*}{$\begin{array}{l}\text { Ker Partmer } \\
\text { - PT. Sidogiri } \\
\text { Mandigi Ditore } \\
\text { (Supplier) } \\
\text { - Retailers. } \\
\text { agents and } \\
\text { Consumers } \\
\text { - Resource } \\
\text { providers } \\
\text { (transportation } \\
\text { and } \\
\text { warehouses) }\end{array}$} & \multirow{3}{*}{$\begin{array}{l}\text { - Ker Activities } \\
\text { Ordering and } \\
\text { shipping to the } \\
\text { products to the } \\
\text { warehouse of PI } \\
\text { DAS } \\
\text { - Receiving and } \\
\text { storing products } \\
\text { in warehouse } \\
\text { - Distribution of } \\
\text { Doduk to } \\
\text { customer } \\
\text { locations } \\
\text { - Market analysis } \\
\text { and planning }\end{array}$} & \multirow{2}{*}{$\begin{array}{l}\text { Value Propositio } \\
\text { - product } \\
\text { distribution } \\
\text { services } \\
\text { - Fast delivery. } \\
\text { day service } \\
\text { - Product quality i } \\
\text { guarantesd } \\
\text { - Serve customes } \\
\text { large quantities } \\
\text { - Strategic } \\
\text { warehouse } \\
\text { location }\end{array}$} & \begin{tabular}{|l|} 
Customer \\
- $\frac{\text { Relationships }}{\text { Customer Service }}$ \\
- Website \& Social \\
Media \\
- Articles and tips \\
- Program sedeliah \\
air \\
- Program bonus \& \\
casbback
\end{tabular} & \multirow{4}{*}{$\begin{array}{l}\text { Customer } \\
\text { - Segments } \\
\text { Household } \\
\text { customers } \\
\text { - Retail } \\
\text { customas and } \\
\text { agents } \\
\text { (product } \\
\text { resellers) } \\
\text { - The mosque } \\
\text { - Banks, } \\
\text { government } \\
\text { agencies, } \\
\text { hotels, } \\
\text { restaurants, } \\
\text { offices, } \\
\text { hospitals, } \\
\text { schools and }\end{array}$} \\
\hline & & & - Bormas and casthat & \\
\hline $\begin{array}{l}\text { - Brona } \\
\text { ambossonos }\end{array}$ & & \multirow{3}{*}{ 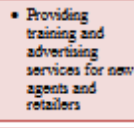 } & pay on time & \\
\hline - investar & \multirow{2}{*}{$\begin{array}{l}\text { - Naximizo offlins } \\
\text { promotion and } \\
\text { mathoting } \\
\end{array}$} & & $\begin{array}{l}\text { - Prograngrest } \\
\text { cossomers }\end{array}$ & \\
\hline \multirow{6}{*}{ 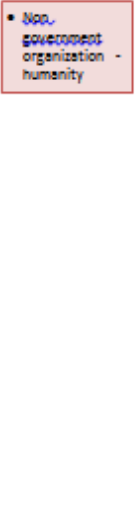 } & & & Collsboration & - Dotormino 1 \\
\hline & $\begin{array}{l}\text { - Training for } \\
\text { employee }\end{array}$ & 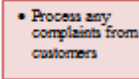 & $\begin{array}{l}\text { humanitarien NGOS } \\
\text { for program } \\
\text { sedekst air mioum }\end{array}$ & 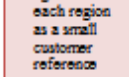 \\
\hline & & $\begin{array}{l}\text { - Routing } \\
\text { ovvatuation to } \\
\text { improves senvices }\end{array}$ & $\begin{array}{l}\text { Hold regular events } \\
\text { with regular } \\
\text { customers }\end{array}$ & \\
\hline & \begin{tabular}{|l|} 
Ker Resources \\
- Warehouse \\
- Transportation \\
(Pickup \& fassa) \\
- Information \\
technology \\
- HR \\
- Company \\
funds \\
\end{tabular} & & $\begin{array}{l}\text { - Channels } \\
\text { Website and social } \\
\text { media } \\
\text { - Sponsorship } \\
\text { (sponsorship of } \\
\text { student activities } \\
\text { and Islamix events) } \\
\text { - Business and } \\
\text { entreprenaur } \\
\text { exhibition }\end{array}$ & \\
\hline & $\begin{array}{l}\text { - Incrouss tho menter } \\
\text { of omployos }\end{array}$ & & - Ads radio notmothar & \\
\hline & & & $\begin{array}{l}\text { magations, brotiras } \\
\text { and onling abop }\end{array}$ & \\
\hline \multirow{2}{*}{\multicolumn{3}{|c|}{$\begin{array}{l}\text { Cost Structure } \\
\text { - Office operational costs } \\
\text { - Operational activity costs } \\
\text { - Sales and promotion costs } \\
\text { - Inventory costs } \\
\text { - Cost of Human Resources } \\
\text { - Warehouse rental and operational costs } \\
\text { - Vehicle rental and operational costs }\end{array}$}} & \multicolumn{2}{|c|}{ - $\frac{\text { Revenue Stream }}{\text { Air NineralSanti Sales }}$} \\
\hline & & & \multicolumn{2}{|c|}{ 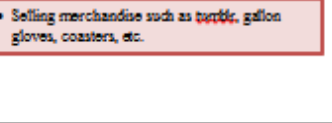 } \\
\hline
\end{tabular}

[4] Kottler, P., \& Keller, L. K. (2009). Manajemen Pemasaran, terjemahan (13th ed.). Jakarta: Erlangga.

[5] Nejad, T. A., Behbodi, M. R., \& Ravanfar, M. M. (2015). Analyzing Organizational Structure based on $7 \mathrm{~s}$ model of McKinsey. International Journal of Academic Research in Business and Social Sciences.

[6] Osterwalder, A., Pigneur, Y., Smith, A., \& Movement, T. (2010). Business Model Generation. New Jersey: John Wiley \& Sons, Inc.

[7] Porter, M. E. (1979). How Competitive Forces Shape Strategy. Harvard Business Review.

[8] Porter, M. E. (2008). The Five Competitive Forces That Shape Strategy. Harvard Business Review.

[9] Purnomo, K. R. (2016). Strategy Formulation For Reinventing BADAK LNG Business Model. In Journal of Industrial Practice.

[10] Rangkuti, F. (1997). Analisis SWOT - Teknik Membedah Kasus Bisnis. Jakarta: Gramedia Pustaka Utama.

[11] Tjitradi, E. C. (2015). Evaluasi Dan Perancangan Model Bisnis Pada Kaisar Organizer Dengan Business Model Canvas. Agora.

[12] Wardhana, A. (2014). Business Model Canvas Penerapannya Pada Industri Jasa Pertambangan Batubara Di Indonesia. Bandung: PT. Karya Manunggal Lithomas.

[13] Waterman, R. H., Peters, T. J., \& Phillips, J. R. (1980). Structure is not organization. Business Horizons, 23(3).

[14] Wheelen, T. L., \& Hunger, J. D. (2012). Strategic Management and Business Policy. New Jersey: Pearson Education.

[15] Wijaya, L. E., \& Indriyani, R. (2016). Analisis Business Model Canvas Pada CV. Kayu Murni Surabaya. Agora. 